\title{
Down-regulation of ghrelin receptors in the small intestine delays small intestinal transit in vagotomized rats
}

\author{
CHENG-GUANG YANG*, WEN-CAI QIU*, ZHI-GANG WANG, SONG YU, JUN YAN and QI ZHENG \\ Department of General Surgery, The Sixth Hospital Affiliated with Shanghai Jiao Tong University, Shanghai 200233, P.R China
}

Received May 9, 2011; Accepted August 19, 2011

DOI: $10.3892 / \mathrm{mmr} .2011 .571$

\begin{abstract}
Vagal nerve injury may occur in esophageal and gastric surgeries. The aim of this study was to observe the effects of ghrelin on small intestinal motility upon vagal nerve injury and the possible co-relationship between changes in ghrelin receptor expression in the small intestine and delayed small intestinal transit after vagotomy. The effects of intraperitoneal administration of ghrelin (20, 40 and $80 \mu \mathrm{g}$ / $\mathrm{kg}$ ) and the ghrelin receptor antagonist [D-Lys ${ }^{3}$ ]-GHRP-6 $(1.5 \mu \mathrm{mol} / \mathrm{kg})$ on small intestinal transit were studied in control and vagotomized rats in vivo. The effects of ghrelin $(0.01,0.1$, $0.5,1.0$ and $2.0 \mu \mathrm{mol} / \mathrm{l}$ ) on the contraction force of smooth muscle strips from the jejunum were studied in the presence or absence of carbachol (50 nmol/l) and [D-Lys ${ }^{3}$-GHRP-6 $(10 \mu \mathrm{mol} / \mathrm{l})$ in vitro. Ghrelin receptor expression was assessed in intestinal muscle layers by means of Western blotting. The results indicated that ghrelin dose-dependently increased small intestinal transit in the control and model rats. In addition, ghrelin enhanced smooth muscle strip contraction induced by carbachol. Ghrelin receptor antagonist [D-Lys3]GHRP-6 blocked the effect of ghrelin. Ghrelin receptor expression in the small intestinal muscle layers was downregulated in the vagotomized rats. Down-regulation of growth hormone secretagogue receptor 1a in small intestinal muscle layers, which affected the function of ghrelin, may be one of the mechanisms behind delayed small intestinal transit after vagotomy.
\end{abstract}

\section{Introduction}

Growth hormone secretagogue receptor type la (ghrelin receptor, GHS-R1a) is a specific G protein-coupled receptor (1).

Correspondence to: Dr Qi Zheng, Department of General Surgery, The Sixth Hospital Affiliated with Shanghai Jiao Tong University, Shanghai 200233, P.R. China

E-mail: sh6zhq@163.com

*Contributed equally

Key words: ghrelin, small intestinal transit, growth hormone secretagogue receptor 1a, vagotomy
It has been found in tissues of the central nervous system, such as the hypothalamus and anterior pituitary gland (2,3), as well as in multiple peripheral organs and tissues $(4,5)$, such as the stomach, intestine (6), pancreas (7) and kidney (8).

Ghrelin is an endogenous ligand for GHS-R la (1). Ghrelin was initially identified because of its function of stimulating the release of growth hormone (9). Following this discovery, a wide variety of biological functions of ghrelin have been determined. It is known to stimulate appetite (10) and a positive energy balance (11); it has cardiovascular actions (12) and controls digestive motility (13-15).

The effect of ghrelin on gastrointestinal tract motility has been of increasing interest. Both central and peripheral administration of ghrelin increased the gastric emptying rate (16) and the frequency of phase III of the interdigestive migrating myoelectric complex (MMC) (17). Furthermore, it induced fasting motor activity in fed rats (13). Previous studies have indicated that ghrelin acts through nervous pathways. Centrally, ghrelin acts through activation of ghrelin receptors in the hypothalamus. When the vagal nerve is severed, its central effects are abolished $(6,18,19)$. Peripheral effects of ghrelin may be caused by activation of ghrelin receptors on the vagal nerve (13) and gastrointestinal enteric plexus (17). Although expression of ghrelin receptors has been detected in the small intestine, changes in ghrelin receptor expression, which may affect the effect of ghrelin on small intestinal transit after the vagal nerve is severed have not yet been reported.

Better understanding of the effects of ghrelin on small intestinal transit and smooth muscle contraction and the association of expression levels of ghrelin receptors may help explain the phenomenon of delayed small intestinal transit after surgery involving trauma of the vagal nerve $(20,21)$.

\section{Materials and methods}

Animals. All animal procedures were conducted according to the ethical guidelines of Shanghai Jiaotong University. Sixty-four male Sprague-Dawley rats $(250 \pm 50 \mathrm{~g})$ were obtained from the Shanghai Laboratory Animal Center, Academia Sinica, China. Rats were housed in stainless steel cages at a controlled humidity $(60-65 \%)$ and temperature $\left(22 \pm 2^{\circ} \mathrm{C}\right)$ with a normal 12:12 h light/dark cycle for at least 7 days before the surgical procedure (22). Thirty-two male Sprague-Dawley rats were randomly selected as controls, the rest underwent vagotomy. 
Preparation of the animal model. According to previously reported surgical procedures $(22,23)$, all rats were anaesthetized with ketamine $(100 \mathrm{mg} / \mathrm{kg})$. After a midline incision to the upper abdominal wall, the lower part of the esophagus was exposed and the posterior branch of the vagal nerve was exposed and incised under a surgical microscope. During surgery a polyethylene microcatheter (inside diameter, $1.2 \mathrm{~mm}$; outside diameter, $1.7 \mathrm{~mm}$ ) was chronically implanted in the duodenum via the stomach, $1 \mathrm{~cm}$ distal to the pylorus, then fixed with sutures to the stomach wall. The catheter was tunneled subcutaneously to exit at the back of the animal's neck $(24,25)$. Animals were housed individually and were given free access to food and water $6 \mathrm{~h}$ after surgery. Control animals underwent surgical procedures as described above, but vagotomy was not performed. The completeness of vagotomy was confirmed by morphological studies for cholinergic nerve fibres in the gastrointestinal tract as described in a previous study (23).

Small intestinal transit. Animals were allowed 3 days to recover before measurements. During recovery, animals were trained daily to accept experimental conditions by injection of 0.2 - $\mathrm{ml}$ trypan blue semi-liquid test meal $(50 \mathrm{mg} / 100 \mathrm{ml}$ in distilled $\mathrm{H}_{2} \mathrm{O}$ with $1.5 \%$ methylcellulose) followed by a $0.2-\mathrm{ml}$ saline flush via the catheters. Trypan blue is a non-absorbable enteral dye marker (22). Measurements were performed in conscious animals after a $12 \mathrm{~h}$ fasting period.

Ghrelin (20, 40 or $80 \mu \mathrm{g} / \mathrm{kg})$ was administered intraperitoneally (i.p.) to the vagotomized and control rats immediately after injection of $0.2 \mathrm{ml}$ trypan blue semi-liquid test meal via the catheter. Trypan blue injection was immediately followed by a $0.2 \mathrm{ml}$ saline flush. This method was performed as described previously $(22,26)$. Rats were sacrificed by cervical dislocation $30 \mathrm{~min}$ after administration of ghrelin. The distances of phenol red transit and the full length of the intestine (from pylorus to ileocecal valves) were calculated. Small intestine transit (\%) was assessed by using the percentage ratio of trypan blue transit over the full intestinal length $(25,27)$.

We also studied the effect of ghrelin $(40 \mu \mathrm{g} / \mathrm{kg})$ on small intestinal transit in control and vagotomized rats after rats were pretreated with [D-lys ${ }^{3}$-GHRP-6 $(1.5 \mu \mathrm{mol} / \mathrm{kg})$ for $10 \mathrm{~min}$.

Organ bath. Control and model rats ( $\mathrm{n}=6$ per group) were sacrified by cervical dislocation. Segments of the proximal intestine were quickly removed and placed in cold Krebs solution (gassed with $95 \% \mathrm{O}_{2} / 5 \% \mathrm{CO}_{2}$ ). Preparation of smooth muscle strips was performed with the help of a microscope (magnification, x10). Circular muscle strips (length, $10 \mathrm{~mm}$; width, $2 \mathrm{~mm}$ ), stripped of mucosa and submucosa, were suspended vertically in a $5 \mathrm{ml}$ organ bath chamber filled with Krebs solution containing $121.5 \mathrm{mM} / 1 \mathrm{NaCl}, 4.7 \mathrm{mM} / 1 \mathrm{KCl}$, $2.5 \mathrm{mM} / 1 \mathrm{CaCl}_{2}, 1.2 \mathrm{mM} / 1 \mathrm{MgSO}_{4}, 1.2 \mathrm{mM} / 1 \mathrm{KH}_{2} \mathrm{PO}_{4}$, $25.0 \mathrm{mM} / 1 \mathrm{NaHCO}_{3}$ and $5.6 \mathrm{mM} / 1$ glucose. The organ bath chamber was gassed with $95 \% \mathrm{O}_{2} / 5 \% \mathrm{CO}_{2}$ and warmed to $37^{\circ} \mathrm{C}$. One end of the muscle strip was fixed to a hook at the bottom of the chamber while the other end was connected by a thread to an external isometric force transducer (Harvard Apparatus, South Natick, USA) at the top. Values for isometric tension obtained from the isometric force transducer were continuously recorded and stored on a computer

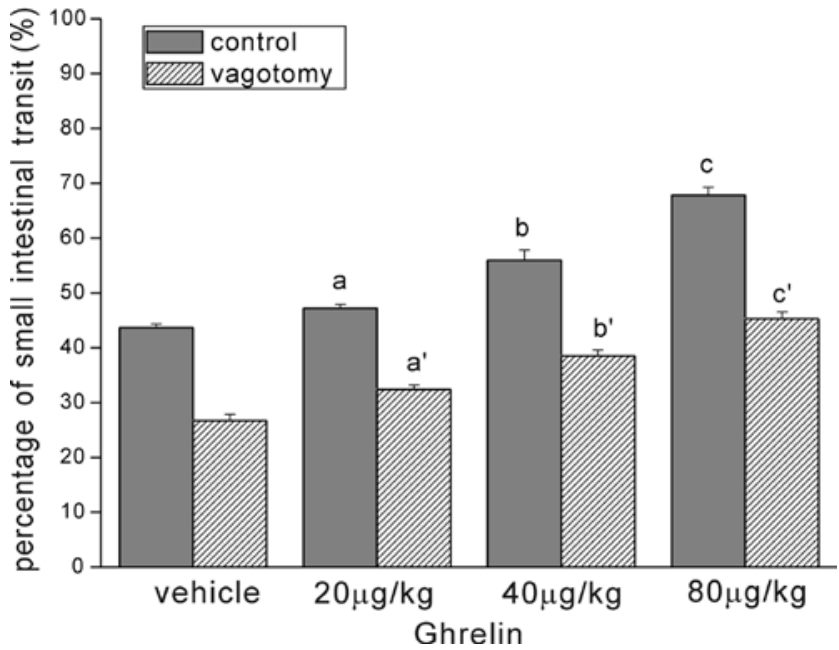

Figure 1. Effect of ghrelin $(0,20,40$ and $80 \mu \mathrm{g} / \mathrm{kg})$ on small intestinal transit $(\%)$ in the control and vagotomized rats. ${ }^{\mathrm{a}} \mathrm{p}<0.01,{ }^{\mathrm{ab}} \mathrm{p}<0.01,{ }^{\mathrm{bc}} \mathrm{p}<0.01$; ${ }^{\mathrm{a}^{\prime}} \mathrm{p}<0.01,{ }^{\mathrm{a} b \mathrm{~b}} \mathrm{p}<0.01,{ }^{\mathrm{b}^{\prime} \mathrm{c}^{\prime}} \mathrm{p}<0.01 ;{ }^{\mathrm{aa}} \mathrm{p}<0.01,{ }^{\mathrm{bb}} \mathrm{p}<0.01,{ }^{\mathrm{cc}} \mathrm{p}<0.01, \mathrm{n}=4$ per condition Mean \pm SEM.

by the SMUP-E biological signal processing system (Chengdu Equipment Factory, China). The strips were stretched to a tension of $0.1 \mathrm{~g}$ and allowed to equilibrate for $40 \mathrm{~min}$. The buffer was changed every $10 \mathrm{~min}$. Measurements were carried out after $1 \mathrm{~h}$ of equilibration.

In this study, the effects of ghrelin $(0.01,0.1,0.5,1.0$ and $2.0 \mu \mathrm{mol} / \mathrm{l}$ ) on the contraction force of smooth muscle strips were studied in the presence or absence of carbachol (Cch; $50 \mathrm{nmol} / \mathrm{l})$ and [D-Lys $\left.{ }^{3}\right]$-GHRP-6 (10 $\left.\mu \mathrm{mol} / \mathrm{l}\right)$. Results were expressed as the percentage of maximal contractile amplitudes induced by Cch (23).

Western blotting. Ghrelin receptor expression was evaluated by Western blotting in small intestinal muscle layers of the control and model rats ( $\mathrm{n}=6$ per group). Proximal intestinal muscle layers were stripped of mucous and submucous layers, lysed with RIPA lysate solution, skived and centrifuged for $10 \mathrm{~min}$ at $12000 \mathrm{x} \mathrm{g}$ and $4^{\circ} \mathrm{C}$. Liquid supernatants were collected for Western blotting. SDS-PAGE electrophoresis was performed with a $10 \%$ gel. Polyvinylidene fluoride (PVDF) membranes were blocked with 5\% skim milk solution. GHS-R1a (44 kDa) (F-16) (goat anti-rat) was diluted in 5\% dried skimmed milk solution and added to the PVDF membranes at a ratio of 1:100. Membranes were incubated at $4^{\circ} \mathrm{C}$ overnight. Secondary antibodies (rabbit anti-goat) coupled by alkaline phosphatase (AP), were added to the PVDF membranes at a ratio of 1:200 and incubated for $2 \mathrm{~h}$. NBT/BICP was used for color development. $\beta$-actin (43 kDa) (mouse anti-rat) was used as an internal control.

Drugs and chemicals. Rat ghrelin, carbachol and [D-Lys ${ }^{3}$-GHRP-6 (ghrelin receptor antagonist) were obtained from Tocris Cookson (Bristol, UK). GHS-R1a (F-16) (goat anti-rat) and $\beta$-actin (mouse anti-rat) were obtained from Santa Cruz (CA, USA). AP-conjugated second antibody (rabbit anti-goat) and AP-conjugated second antibody (goat anti-mouse) were obtained from Jackson Immuno Research Inc. (West Grove, PA, USA). 


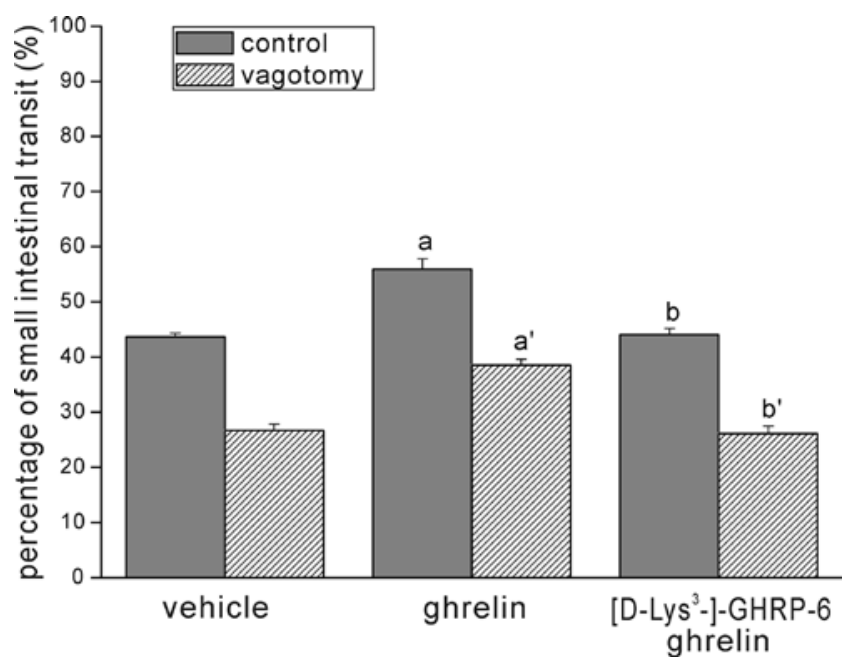

Figure 2. Effect of $40 \mu \mathrm{g} / \mathrm{kg}$ ghrelin on small intestinal transit (\%) with and without pre-treatment with [D-Lys ${ }^{3}$-GHRP-6 $(1.5 \mu \mathrm{M} / \mathrm{kg})$ in the control and vagotomized rats. ${ }^{a b} \mathrm{p}<0.01,{ }^{\mathrm{b}} \mathrm{p}>0.05 ;{ }^{\mathrm{a} \mathrm{b}^{\prime}} \mathrm{p}<0.01,{ }^{\mathrm{b}^{\prime}} \mathrm{p}>0.05, \mathrm{n}=4$ per condition. Mean \pm SEM.

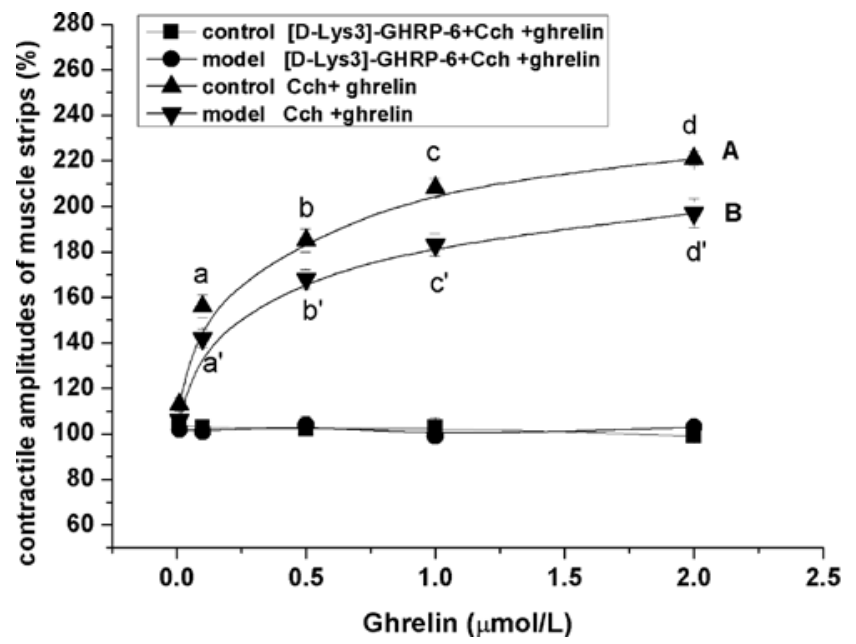

Figure 3. Effect curves (\%) of ghrelin on small intestinal smooth muscle strips in the presence of carbachol $(50 \mathrm{nmol} / \mathrm{l})$ or [D-Lys ${ }^{3}$ ]-GHRP-6 $(10 \mu \mathrm{mol} / \mathrm{l})+$ carbachol $(50 \mathrm{nmol} / \mathrm{l})$ in the control and vagotomized rats. In curve $\mathrm{A},{ }^{\mathrm{a}} \mathrm{p}<0.01,{ }^{\mathrm{ab}} \mathrm{p}<0.01,{ }^{\mathrm{bc}} \mathrm{p}<0.01$; in curve $\mathrm{B},{ }^{\mathrm{a}} \mathrm{p}<0.01,{ }^{\mathrm{a} b} \mathrm{p}<<0.01,{ }^{{ }^{\prime} c^{\prime}} \mathrm{p}<0.01$; between curve $A$ and $B,{ }^{a a^{\prime}} p>0.05,{ }^{b b^{\prime}} p<0.05,{ }^{c{ }^{\prime}} p<0.01,{ }^{\text {dd }} p<0.01, n=6$ per condition. Mean \pm S.E.M. Cch: carbachol.

Statistical analysis. Results are expressed as the mean \pm SEM. Data were analyzed with the Origin 8.0 software. Photoshop 8.0.1 software and CorelDRAW X4 software were used to process the figures. Quantity 4.6.2 software was used to analyze the staining intensity. Data recordings were evaluated by one way analysis of variance (ANOVA) followed by Dunnett's test. $\mathrm{p}<0.05$ was considered statistically significant.

\section{Results}

Effect of ghrelin on small intestinal transit. There was a statistically significant difference in small intestinal transit (\%) between the control and vagotomized rats when no ghrelin was injected $(42.73 \pm 0.53$ vs. $25.32 \pm 1.02 \% ; \mathrm{p}<0.01, \mathrm{n}=5$ per condition). Ghrelin increased small intestinal transit in the

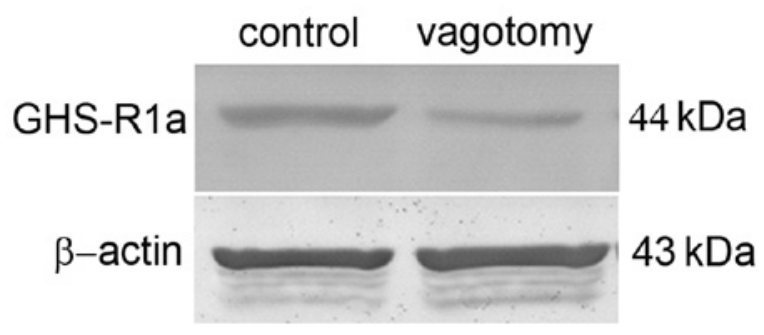

Figure 4. Expression of ghrelin receptors in small intestinal muscle layers in control and vagotomized rats as determined by Western blot bands.

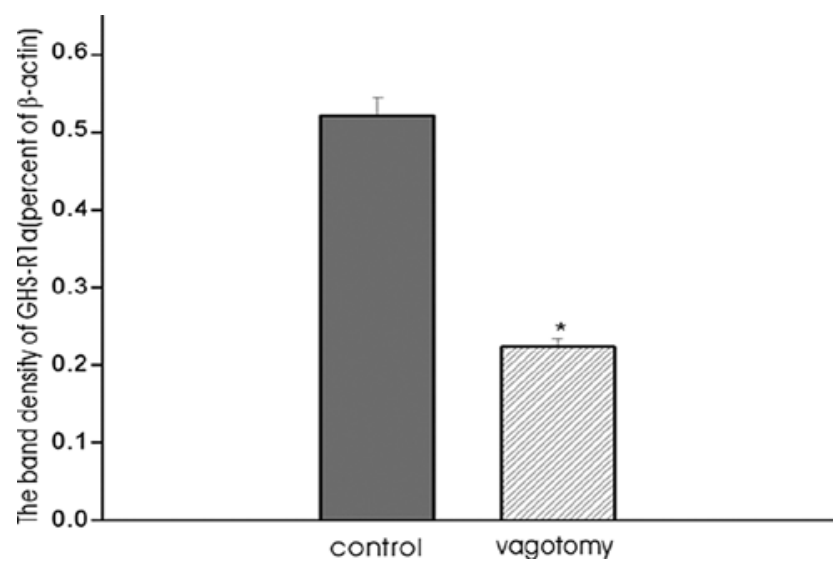

Figure 5. Results of the Western blot analysis of ghrelin receptor expression levels (percent of $\beta$-actin) in small intestinal muscle layers in control and vagotomized rats. ${ }^{*} \mathrm{p}<0.01, \mathrm{n}=6$ per condition. Mean \pm SEM.

control and model rats in a dose-dependent manner (Fig. 1). [D-Lys ${ }^{3}$ ]-GHRP-6 blocked the effect of ghrelin $(40 \mu \mathrm{g} / \mathrm{kg})$ (Fig. 2).

Effect of ghrelin on smooth muscle strip contraction in vitro. Ghrelin did not increase smooth muscle strip contraction in the absence of carbachol. However, when carbachol $(50 \mathrm{nmol} / \mathrm{l})$ was applied, ghrelin did increase smooth muscle strip contraction, and a statistically significant difference in smooth muscle strip contractile amplitudes was noted in the control and vagotomized rats with an increased dose of ghrelin (Fig. 3). [D-Lys ${ }^{3}$ ]-GHRP-6 blocked the effect of ghrelin (Fig. 3), but no significant difference was noted in the smooth muscle strip contractile amplitudes between the control and vagotomized rats ( $p>0.05 ; n=6$ per condition).

Western blot analysis. Ghrelin receptor expression was confirmed in the small intestinal muscle layers (Fig. 4). Lower expression of ghrelin receptors was observed in the small intestinal muscle layers of the vagotomized rats when compared with that of the controls (Fig. 5).

\section{Discussion}

In esophageal and gastric surgery, there is often a delay in gastrointestinal motility, and trauma of the vagal nerve sometimes is involved $(20,21,28)$. When the vagal nerve is injured, the delay in gastrointestinal transit increases (29-31). This delay in small intestinal transit might be caused by 
both central and peripheral mechanisms. When the vagal nerve is severed, the function of motor nerves that regulate small intestinal motility is impaired. This may be the main factor leading to delayed small intestinal transit. Ghrelin can promote gastrointestinal tract motility if administered through central or peripheral channels $(13,15-17)$. Ghrelin exerts its role by activating ghrelin receptors (GHS-R1a) in central or peripheral tissues (2-5). Therefore, we aimed to study the role of ghrelin receptors in delayed small intestinal transit.

In the present study, only the posterior branch of the vagal nerve was severed. The anterior branch of the vagal nerve dominating the liver and anterior stomach was preserved. This accurately cut motor nerves dominating small intestinal motility while it had little effect on gastric motility and metabolism of the liver. Thus, we could observe the effect of vagotomy on growth hormone secretagogue receptor la expression in small intestinal muscle layers with little or no effect on other ventral organs.

In previous studies, administration of ghrelin through the central nervous system had a pronounced effect on appetite and motility of the gastrointestinal tract (32-35). These effects are carried out through the vagal nerve (36). When the vagal nerve was cut, these effects were abolished (18). Peripheral administration of ghrelin also enhanced motility of the gastrointestinal tract $(14,15,17,37)$. In our experiment, ghrelin dose-dependently increased the small intestinal transit in control and model rats in vivo. The ghrelin receptor antagonist [D-Lys ${ }^{3}$ ]-GHRP-6 blocked the effect of ghrelin. These results suggest that ghrelin affects small intestinal motility by activating ghrelin receptors (GHS-R1a).

Concentrations of 20,40 and $80 \mu \mathrm{g} / \mathrm{kg}$ ghrelin were physiological stimulus doses. Under physiological conditions, plasma levels of ghrelin in rats are 500-2000 pmol/1 (38). Fujino et al (13) found that injection of $1.5 \mathrm{nmol}$ of ghrelin per rat resulted in an approximately $600 \mathrm{pmol} / 1$ increase in plasma ghrelin concentrations. Supporting this result, when $80 \mu \mathrm{g} / \mathrm{kg}$ ghrelin was applied in the present study, the plasma concentration was approximately $2400 \mathrm{pmol} / \mathrm{l}$, which approached physiological concentrations. Hence, experimental results were of biological relevance. In vagotomized rats, the vagal nerve was severed while sympathetic nerves were preserved. Under these conditions ghrelin still promoted small intestinal transit. This suggests that ghrelin directly promotes small intestinal transit without participation of the vagal nerve in vivo.

In vitro, ghrelin played a gastroprokinetic-like role when smooth muscle strips were stimulated by an electrical field (39). This phenomenon suggests ghrelin functions only when nerve impulses come into being or membrane potential is altered. Ghrelin was found to enhance smooth muscle strip contraction in the presence of carbachol (40). This suggests that ghrelin amplifies the effect of carbachol; it is just an adjuvant. When carbachol was absent, ghrelin did not promote smooth muscle strip contraction. It is possible that the function of the nerve cells in the smooth muscle strips was suppressed. Carbachol may directly promote smooth muscle strip contraction, or it may activate nerve cells in smooth muscle strips by direct stimulation. When nerve cells are activated, ghrelin may function by activating ghrelin receptors on the nerve cells. Further studies should be carried out to clarify this mechanism.
The effective doses of ghrelin were different in vivo than in vitro. In vitro, a 50-fold higher concentration was needed to promote smooth muscle strip contraction than in vivo. We speculated that there was a gradually decreasing concentration from the organ bath chamber to nerve cells in the muscle layers. In addition, delayed tissue fluid exchange in vitro might affect the diffusion of the experimental medicine.

Western blot analysis and ghrelin receptor staining both indicated that there was a decreasing trend in ghrelin receptor expression in the vagotomized rats. These results can explain those from the in vivo and in vitro experiments.

In conclusion, ghrelin increased small intestinal transit in control and vagotomized rats. Ghrelin affected small intestinal motility by activating ghrelin receptors in intestinal muscle layers without participation of the vagal nerve. After vagotomy, expression levels of ghrelin receptors were down-regulated. Ghrelin receptor down-regulation affected the effect of ghrelin. This may be one of the mechanisms behind delayed small intestinal transit after surgery resulting in trauma of the vagal nerve.

\section{References}

1. Van der Lely AJ: Biological, physiological, pathophysiological, and pharmacological aspects of ghrelin. Endocr Rev 25: 426-457, 2004.

2. Guan XM, Yu H, Palyha OC, et al: Distribution of mRNA encoding the growth hormone secretagogue receptor in brain and peripheral tissues. Brain Res Mol Brain Res 48: 23-29, 1997.

3. Shuto Y, Shibasaki T, Wada K, et al: Generation of polyclonal antiserum against the growth hormone secretagogue receptor (GHS-R): Evidence that the GHS-R exists in the hypothalamus, pituitary and stomach of rats. Life Sci 68: 991-996, 2001.

4. Kojima M, Hosoda H and Kangawa K: Purification and distribution of ghrelin: the natural endogenous ligand for the growth hormone secretagogue receptor. Horm Res 56 (Suppl 1): 93-97, 2001.

5. Yokote R, Sato M, Matsubara S, et al: Molecular cloning and gene expression of growth hormone-releasing peptide receptor in rat tissues. Peptides 19: 15-20, 1998.

6. Date Y: Ghrelin, a novel growth hormone-releasing acylated peptide, is synthesized in a distinct endocrine cell type in the gastrointestinal tracts of rats and humans. Endocrinology 141: 4255-4261, 2000.

7. Kamegai J, Tamura H, Shimizu T, et al: Central effect of ghrelin, an endogenous growth hormone secretagogue, on hypothalamic peptide gene expression. Endocrinology 141: 4797-4800, 2000.

8. Mori K, Yoshimoto A, Takaya K, et al: Kidney produces a novel acylated peptide, ghrelin. FEBS Lett 486: 213-216, 2000.

9. Kojima M, Hosoda H, Date Y, et al: Ghrelin is a growthhormone-releasing acylated peptide from stomach. Nature 402: 656-660, 1999.

10. Dimaraki EV and Jaffe CA: Role of endogenous ghrelin in growth hormone secretion, appetite regulation and metabolism. Rev Endocr Metab Disord 7: 237-249, 2006.

11. Asakawa A: Stomach regulates energy balance via acylated ghrelin and desacyl ghrelin. Gut 54: 18-24, 2005.

12. Nagaya $\mathrm{N}$ and Kangawa $\mathrm{K}$ : Ghrelin, a novel growth hormonereleasing peptide, in the treatment of chronic heart failure. Regul Pept 114: 71-77, 2003.

13. Fujino K, Inui A, Asakawa A, et al: Ghrelin induces fasted motor activity of the gastrointestinal tract in conscious fed rats. J Physiol 550: 227-240, 2003.

14. Tack J: Influence of ghrelin on interdigestive gastrointestinal motility in humans. Gut 55: 327-333, 2006.

15. Taniguchi H: Effects of ghrelin on interdigestive contractions of the rat gastrointestinal tract. World J Gastroenterol 14: 6299, 2008.

16. Trudel L, Tomasetto C, Rio MC, et al: Ghrelin/motilin-related peptide is a potent prokinetic to reverse gastric postoperative ileus in rat. Am J Physiol Gastrointest Liver Physiol 282: G948-G952, 2002. 
17. Edholm T: Ghrelin stimulates motility in the small intestine of rats through intrinsic cholinergic neurons. Regul Pept 121: 25-30, 2004

18. Kamiji MM, Troncon LE, Antunes-Rodrigues J, et al: Ghrelin and PYY(3-36) in gastrectomized and vagotomized patients: relations with appetite, energy intake and resting energy expenditure. Eur J Clin Nutr 64: 845-852, 2010.

19. le Roux CW, Neary NM, Halsey TJ, et al: Ghrelin does not stimulate food intake in patients with surgical procedures involving vagotomy. J Clin Endocrinol Metab 90: 4521-4524, 2005.

20. Shafi MA and Pasricha PJ: Post-surgical and obstructive gastroparesis. Curr Gastroenterol Rep 9: 280-285, 2007.

21. Shah D, Dumonceau JM, Burri H, et al: Acute pyloric spasm and gastric hypomotility: An extracardiac adverse effect of percutaneous radiofrequency ablation for atrial fibrillation. J Am Coll Cardiol 46: 327-330, 2005.

22. Tebbe JJ, Mronga S, Tebbe CG, et al: Ghrelin-induced stimulation of colonic propulsion is dependent on hypothalamic neuropeptide Y1- and corticotrophin-releasing factor 1 receptor activation. J Neuroendocrinol 17: 570-576, 2005.

23. Fujino K, Inui A, Asakawa A, et al: Ghrelin induces fasting motor activity of the gastrointestinal tract in conscious fed rats. J Physiol 550: 227-240, 2003

24. Sallam HS, Oliveira HM, Gan HT, et al: Ghrelin improves burninduced delayed gastro- intestinal transit in rats. Am J Physiol Regul Integr Comp Physiol 292: R253-R257, 2007.

25. Zheng Q, Qiu WC, Yan J, et al: Prokinetic effects of a ghrelin receptor agonist GHRP-6 in diabetic mice. World J Gastroenterol 14: 4795-4799, 2008.

26. Monnikes H, Raybould HE, Schmidt B, et al: CRF in the paraventricular nucleus of the hypothalamus stimulates colonic motor activity in fasted rats. Peptides 14: 743-747, 1993.

27. Qiu WC, Wang ZG, Lv R and Ai KX: Ghrelin improves delayed gastrointestinal transit in alloxan-induced diabetic mice. World J Gastroenterol 14: 2572-2577, 2008.

28. Trus TL, Bax T, Richardson WS, et al: Complications of laparoscopic paraesophageal hernia repair. J Gastrointest Surg 1: 221-227, 1997

29. Noguchi E, Ohsawa H, Tanaka H, et al: Electro-acupuncture stimulation effects on duodenal motility in anesthetized rats. Jpn J Physiol 53: 1-7, 2003.
30. Van der Mijle HC, Kleibenker JH, Limburg AJ, et al: Role of vagal dysfunction in motility and transit disorders of jejunal Roux limb after Roux-en-Y gastrojejunostomy. Dig Dis Sci 39: 827-833, 1994

31. Hellstróm PM: Vagotomy inhibits the effect of neurotensin on gastrointestinal transit in the rat. Acta Physiol Scand 128: 47-55, 1986.

32. Kamiji MM, Troncon LE, Suen VM, et al: Gastrointestinal transit, appetite, and energy balance in gastrectomized patients. Am J Clin Nutr 89: 231-239, 2008.

33. Kobashi M, Yanagihara M, Fujita M, et al: Fourth ventricular administration of ghrelin induces relaxation of the proximal stomach in the rat. Am J Physiol Regul Integr Comp Physiol 296: R217-R223, 2009.

34. Seoane LM, Lopez M, Tovar S, et al: Agouti-related peptide, neuropeptide $\mathrm{Y}$, and somatostatin-producing neurons are targets for ghrelin actions in the rat hypothalamus. Endocrinology 144: 544-551, 2003

35. Tups A, Helwig M, Khorooshi RM, et al: Circulating ghrelin levels and central ghrelin receptor expression are elevated in response to food deprivation in a seasonal mammal (Phodopus sungorus). J Neuroendocrinol 16: 922-928, 2004.

36. Ammori J, Zhang W, Li J, et al: Effects of ghrelin on neuronal survival in cells derived from dorsal motor nucleus of the vagus. Surgery 144: 159-167, 2008.

37. Kobelt P, Tebbe JJ, Tjandra I, et al: CCK inhibits the orexigenic effect of peripheral ghrelin. Am J Physiol Regul Integr Comp Physiol 288: R751-R758, 2005.

38. Murakami N, Hayashida T, Kuroiwa T, et al: Role for central ghrelin in food intake and secretion profile of stomach ghrelin in rats. J Endocrinol 174: 283-288, 2002.

39. Bassil AK, Dass NB and Sanger GJ: The prokinetic-like activity of ghrelin in rat isolated stomach is mediated via cholinergic and tachykininergic motor neurones. Eur J Pharmacol 544: 146-152, 2006.

40. Qiu WC, Wang ZG, Wang WG, et al: Therapeutic effects of ghrelin and growth hormone releasing peptide 6 on gastroparesis in streptozotocin-induced diabetic guinea pigs in vivo and in vitro. Chin Med J (Engl) 121: 1183-1188, 2008. 